International Business and Global Economy 2018, no. 37, pp. 399-408

Biznes międzynarodowy w gospodarce globalnej 2018, nr 37, s. 399-408

Edited by the Institute of International Business, University of Gdańsk

ISSN 2300-6102

e-ISSN 2353-9496

DOI 10.4467/23539496IB.18.029.9402

Artur Klimek

Uniwersytet Ekonomiczny we Wrocławiu

\title{
Advanced business services in the global economy and the Visegrád Group economies
}

The paper aims to present recent trends in global trade and investment in advanced business services (ABS). Special attention is given to the position of Visegrád countries in international movements of services and associated activities. The research method applied in the study is the statistical analysis of aggregate data on trade and foreign direct investment (FDI). The data were extracted from the World Trade Organization (WTO) and the Organisation for Economic Cooperation and Development (OECD) databases. The main finding is that services are still less traded than merchandise. Still, knowledge-intensive services are gaining importance as their share in trade of services reaches $15 \%$. As a result of the study, major problems with data regarding services were identified. The results confirm the global importance of the services based on knowledge. This is significant, as ABS create a narrow group of specialized services. Importantly, $\mathrm{ABS}$ are quite inclusive and many emerging economies become global providers of such services.

Keywords: advanced business services, international trade, foreign direct investment, emerging economies, multinational corporations

JEL classification: F14, F21, F23

\section{Zaawansowane usługi biznesowe w gospodarce światowej a gospodarki Grupy Wyszehradzkiej}

Celem artykułu jest przedstawienie najnowszych trendów w globalnym handlu i inwestycjach w obszarze zaawansowanych usług biznesowych (ABS). Szczególną uwagę zwrócono na pozycję państw Grupy Wyszehradzkiej w międzynarodowych przepływach usług i działalności powiązanej. Metodą badawczą zastosowaną w badaniu jest analiza statystyczna zagregowanych danych dotyczących handlu i bezpośrednich inwestycji zagranicznych pochodzących z baz Światowej Organizacji Handlu (WTO) oraz Organizacji Współpracy Gospodarczej i Rozwoju (OECD). Zgodnie z wynikami badań usługi są nadal w mniejszym stopniu przedmiotem obrotu międzynarodowego niż towary, jednak na znaczeniu zyskują usługi wymagające dużej wiedzy, których udział w handlu usługami sięga 15\%. W wyniku przeprowadzonych badań zidentyfikowano poważne problemy dotyczące danych o usługach. Wyniki potwierdzają globalne znaczenie usług opartych na wiedzy. Jest to istotne, ponieważ ABS tworzą wąską grupę specjalistycznych usług. Co ważne, ABS mogą być oferowane przez gospodarki o różnym poziomie rozwoju, a wiele wschodzących gospodarek staje się światowymi dostawcami takich usług.

Słowa kluczowe: zaawansowane usługi biznesowe, handel międzynarodowy, bezpośrednie inwestycje zagraniczne, gospodarki wschodzące, korporacje transnarodowe

Klasyfikacja JEL: F14, F21, F23 


\section{Introduction}

In recent decades, the global economy has been shaped by the evolving international trade and foreign direct investment. Much attention of researchers and policymakers was attracted by flows of tangible items. They took forms of containers or greenfield investment. Less attention was paid to the intangible elements of the global economy - various forms of services. They dominate the flows of FDI and become an important part of the global economy. Services also frequently facilitate international operations of tangible assets. This is the case especially for the distinctive category of advanced business services (ABS), also referred to as knowledge-intensive business services (KIBS).

The development of trade in KIBS is predominantly associated with propensity towards outsourcing or offshoring of many multinational corporations (MNCs) and technology advancement that allows many tasks to be sourced from distant locations. These developments also have a social impact. ABS became a symbol of offshoring of valuable white-collar positions, praised by policymakers as filled predominantly by middle-class people. Certain politicians complain about the decline of the middle class. However, we can also see it rising in other parts of the world.

The aim of the paper is to present recent trends in global trade and investment in ABS. Special attention is given to the position of the Visegrád countries (V4: Czech Republic, Hungary, Poland, and Slovakia) in international movements of services and associated activities. Such a study is justified by the importance for the global economy and V4 countries of the dynamic growth observed in this sector for more than a decade. The key research hypothesis is that services are less traded internationally than merchandise goods due to higher barriers to trade. The research questions are as follows: What is the role of trade in services in the global economy? What are the dynamics of trade of particular categories of services? What is the role of $\mathrm{V} 4$ economies in global trade in ABS? What are the main ABS exported by V4 economies?

The research method applied in the study is the statistical analysis of aggregate data on trade. Numerous indicators are used to investigate the role of various categories of services in global trade. Additionally, an analysis of detailed data regarding particular ABS in V4 economies was carried out. The data were extracted from WTO and OECD databases.

If we were to measure the importance of economic phenomena based on the availability of relevant data, we would have to conclude that services are globally negligible. Although this would be obviously untrue, the problem of internationally comparable and reliable data on services, where inconsistencies and overestimations can be observed, is of grave importance. It can partially explain the bias 
towards publications on merchandise trade or FDI in manufacturing. It also leads to underestimation of the role of services in the modern global economy. This paper is aimed at reducing the knowledge gap concerning the important category of knowledge-intensive services. It also focuses on methodological issues regarding the analysis of ABS.

The remainder of the paper is organized as follows. The first section presents the theoretical background of trade and FDI in services; the second section discusses the results of quantitative analysis; in the last section, concluding remarks are provided.

\section{Theoretical background on ABS and the global economy}

Business services - especially knowledge-intensive - play a recognised role in the economic processes within the economy. They are associated with regional development and innovation [Miles et al., 1995] as well as with the competetiveness of companies and economies [Roberts, 2003]. KIBS create knowledge and facilitate its dissemination among various paricipants of the economic process [Andersen et al., 2000]. Along with KIBS comes the notion of ABS. The former comprise various forms of operations: business process outsourcing, shared service centers, information technology outsourcing, and research and development centers, and are seen from a more business-oriented point of view with less attention to their role in the global economy.

Theory of international exchange of services explains trade and investment in services using two approaches. On the one hand, services are treated as autonomous activities that can be traded with no direct link to trade in physical goods; on the other, they are embedded into or closely linked to goods, and in this case trade in services goes hand in hand with trade in goods. While some services cannot be traded separately from goods, it must be underlined that there can be no trade in goods without services. According to Jones and Kierzkowski [2001, p. 17], services fostered the international fragmentation of production processes in the global economy. Some economists argue that due to this fragmentation, the optic of trade analysis should be changed and focus on trade in tasks [Grossman, RossiHansberg, 2008]. Services are also referred to as "the glue that holds supply chains together and ensures that they function in a fluid manner" [Low, 2013, p. 63].

Among the factors facilitating international transactions in services, the advancement of technology is of high importance. First, information and communication technologies (ICT) increased exports and imports of various services. Second, ICT made some services, earlier non-tradable, easily tradable across borders. Thus, building ICT infrastructure and encouraging its use may be particularly helpful in boosting international trade in services [Nath, Liu, 2017]. 
Improvements in ICT can remove barriers to trade in services. One important barrier to trade in services over large distances is time - i.e., different time zones. The differences may induce additional costs due to the need of synchronisation. However, when it comes to ABS, time difference may become beneficial to businesses that conduct their operations around the clock [Dettmer, 2014]. This also implies that trade in services in the same or nearby time zone can be hampered by lack of continuity.

There is also a new kind of trade emerging - i.e., trade in digital services [Bieron, Ahmed, 2016]. Widespread, inclusive, and low-cost, digital services have a huge impact on other cross-border flows, especially those of traditional industries.

Another important factor of the growing role of services in the international market was the elimination of some barriers to trade. The landmark moment was the introduction in 1995 of the results of the Uruguay Round negotiations in the form of the General Agreement on Trade in Services. This was also the moment when forms of trade in services were defined (so-called four modes of services supply), trade rules for services introduced, and fair treatment and promotion of service trade liberalisation ensured. The latter objective was not met and little progress in removing barriers was achieved, mostly due to many exemptions.

A framework for international trade and FDI in business services ("producer services") was proposed by Markusen, Rutherford, and Tarr [2005]. As they focused on expertise and knowledge, their research is useful in explaining KIBS. Its results confirm that liberalisation of trade in services may lead to an increase in national income and the income of skilled labour. Markusen [1997] modelled the operations of MNCs with respect to international production paying much attention to "knowledge-intensive producer services". FDI in KIBS also play an important role in increasing the capacity of economies and boosting their international trade through knowledge spill-overs of manufacturing and service MNCs in host economies [Brandao Fischer, 2015]. Although the economic theory tries to model and explain cross-border flows of services and international investment in services, the results, especially when it comes to the role of MNCs, are still not satisfactory.

\section{The empirics of trade and investment in ABS with respect to the Visegrád countries}

In the course of recent decades, we could see a growing importance of trade in services in the global economy. It is not surprising that trade in services was referred to as "the most dynamic segment of international trade" by WTO [2015]. What is important, this phenomenon is also gaining momentum in developing economies. Trade in KIBS is growing as companies gravitate more and more to- 
ward service offshoring [Wirzt, Tuzovic, Ehret, 2015], aware that it may increase their international competitiveness, and thus the total value of their business.

Before proceeding to the analysis of data regarding international flows of services and activites related to services, it is important to note the methodological challenges. After studying the data and previous empirical contributions, three types of the already-mentioned measurement problems emerge: underestimation, overestimation, and omittion. All of them are equally important and must be taken into consideration when drawing conclusions.

The source of underestimation is incorrect valuation of services which occurs, e.g., when companies make calculations for internal purposes or when services are combined with physical goods in a way that makes the determination of the value of particular components impossible or pointless, as some goods and services cannot be traded individually.

Overestimation most frequently concerns investment in services, mainly when production companies operate under an umbrella service company or services are used for tax optimization. Is such instances, the value of real service activites may be significantly inflated in order to increase costs and thus decrease taxes, therefore distorting both trade data, by reporting incorrect values, and investment data, when offices are established in low taxes jurisdictions or the actual scale of operations is smaller than officially reported.

Omittion can also be referred to as immaturity of statistical standards. Services, especially knowledge-intensive, are frequently vauge and new, which means that statistical reporting does not accommodate their complexity and evolution. In spite of the drawbacks, there is a grave need to analyse data on services and define the measurement problems.

The problem is even more evident in the case of international trade. According to Low [2013], the volume of international trade in services is underestimated. For example, when the share of services in global trade is measured in gross terms, the result for 2008 is $23 \%$, but $45 \%$ when measured in value added terms.

Since 2011 the share of services in merchandise trade is rising steadily, reaching $30 \%$ in recent years. This testifies to their growing role, but also to the faltering growth of merchandise trade due to changes of commodity prices and weakening demand for resources from the main emerging economy - China. The results concerning ABS are inconclusive. Their share in the global trade in services has been slowly rising to reach over $13 \%$ in 2015 . In the V4 countries, this share is significantly higher than the global average, but since 2013 this growth has been slowing down.

There are several locations in the world offering competitive conditions for locating ABS operations. The most important include India, China, South-East Asia, but also Central and Eastern Europe. Key players in the latter group are the 
Visegrád countries. There are differences in their strategic roles with respect to international trade. Companies in the Czech Republic, similarly to China, focus on supplying domestic markets, while India and Philippines supply foreign markets [Engman, 2007]. However, the role of V4 is changing as they become global suppliers of services focused mainly on the EU and North American markets.

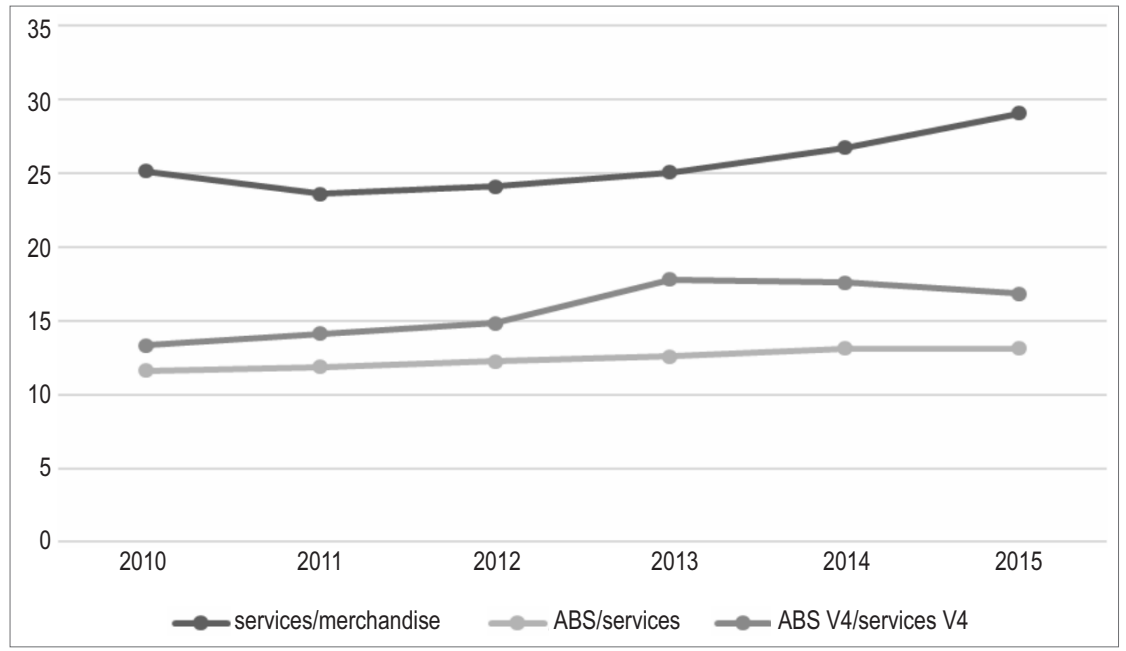

Figure 1. Share of services in international trade (\%)

Source: Own elaboration based on WTO data.

Although the role of V4 in ABS trade is rising in the global perspective, their share is still on a low level - over 3\%. However, when analysing the EU market, a much different picture emerges. The share of V4 reached $10 \%$ of total EU-28 trade and there is a tendency towards further growth in the coming years. This is especially important considering the middling size of the grouping in comparison to other large European economies. It should also be noted that although the V4 countries do not constitute a global ABS hub, from the European perspective they are large international providers of ABS. Importantly, this result was achieved just a few years after the first units providing ABS were established in the V4 countries. Moreover, the rising significance of V4 in this respect occurred in economies with post-industrial structures.

The V4 countries are far from homogeneus when it comes to both the size and structure of their economies as well as the value and dynamics of their trade in ABS. Apart from Slovakia, these countries started from a similar level in 2010, after which the values diverged. Poland became the largest and most dynamic international provider of ABS. In just 5 years, its share rose almost threefold. The Czech Republic and Hungary reported a much slower growth. Importantly, in 2015 the 
two economies faced a decline in the value of trade. The situation is completely different in Slovakia, where the value of ABS trade is singificantly lower than in the other economies and stagnant as a consequence of the undeveloped ABS sector. The results show a correlation between the total value of trade and the value of ABS trade.

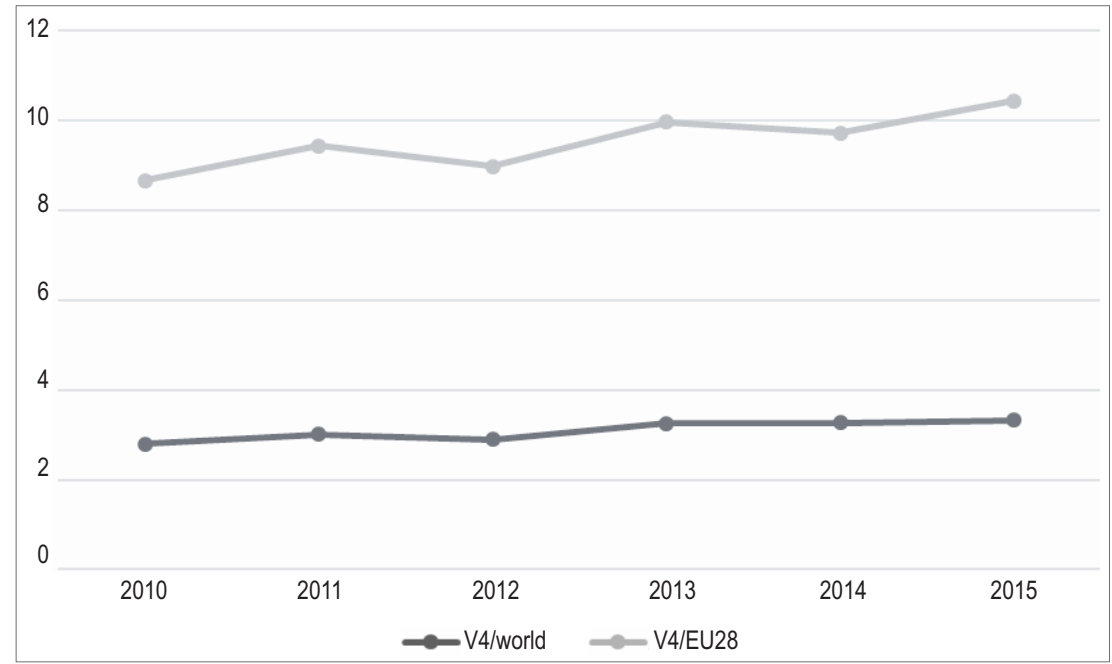

Figure 2. Share of the V4 countries in ABS trade (\%)

Source: Own elaboration based on WTO data.

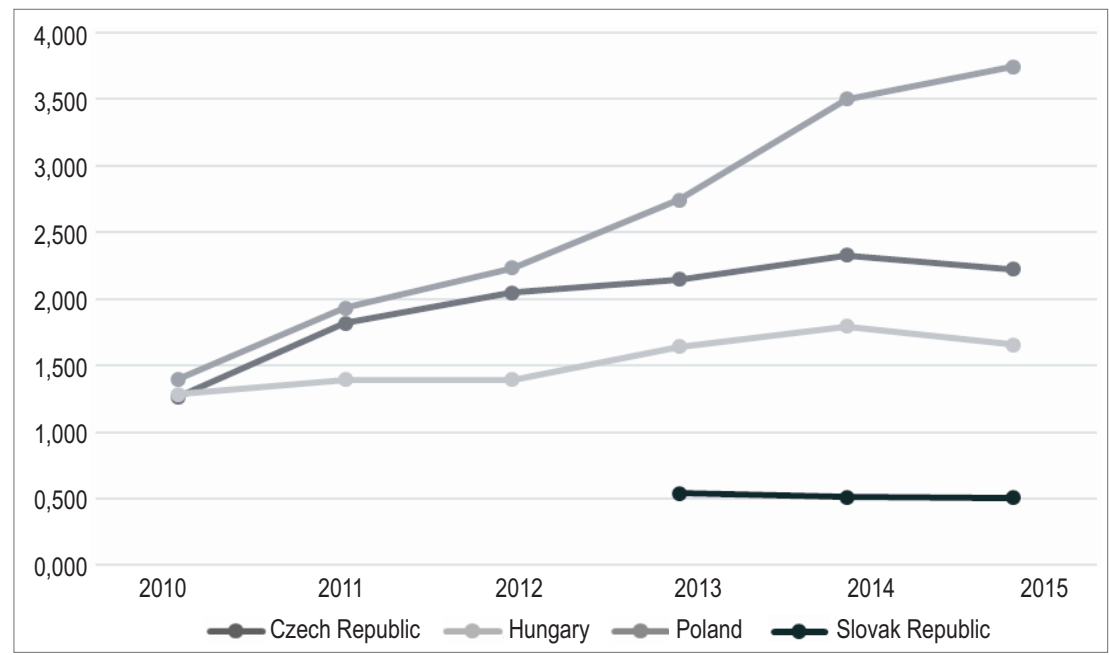

Figure 3. Value of ABS exports in the V4 countries (USD mn)

Source: Own elaboration based on WTO data. 
Important insights are provided by the analysis of the structure of ABS exports in the V4 countries. The most important category are professional and management consulting services, followed by information technology services, and research and development services. Their share is inversely proportional to their knowledge intensity, which means that ABS exports from V4 are dominated by simpler, sometimes repetitive tasks. Such a structure poses a threat of jobs being eliminated by automation and international competition. Moreover, the services sectors in the economies under analysis frequently just exploit the existing skills and knowledge without contributing to their creation.

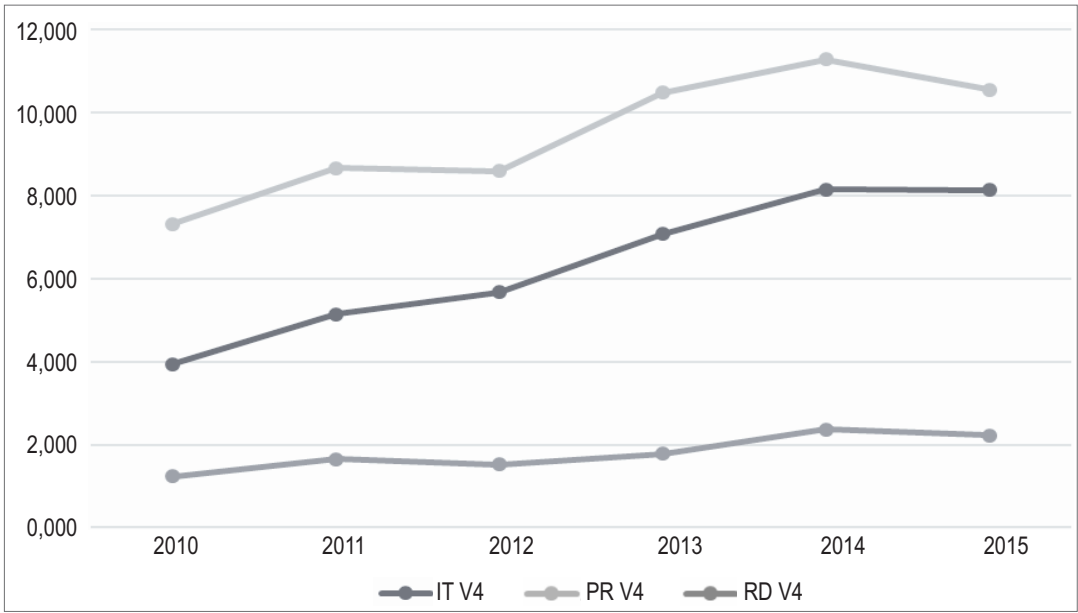

Figure 4. Value of exports of different ABS categories (USD mn)

Notes: PR - professional and management consulting services, IT - information technology services, RD - research and development services.

Source: Own elaboration based on WTO data.

The challenges in the analysis of FDI in services using aggregate data are even bigger than in the case of trade. First of all, many countries do not reveal much data about the flows of FDI in ABS (as opposite to FDI in manufacturing). Out of the V4 countries, only Hungary and Poland provide such data. However, short time span and high volatility do not allow to draw definite conclusions. Therefore, further research on FDI in ABS will not be conducted using aggregate data, but company-level data. Unfortunaly, this adds to the list of problems with the analysis of international flows of services. 


\section{Conclusions}

The paper has been devoted to the presentation of the role of services in global trade and foreign direct investment. The significance of investigating this phenomenon is related to its economic impact and the existence of knowledge gaps. International flows of services are not frequently discussed in the literature due to data limitations and complex methodology. However, progress in the research is crucial in order to establish a new framework of analysis that would include new types of services.

The paper has focused mostly on modern business services and their role in international trade. The main finding was that while services are still less traded than merchandise, knowledge-intensive services are gaining importance and their share in trade of services already reaches $15 \%$. This is especially significant as ABS constitute a narrow group of specialized services. Importantly, their supply requires vast knowledge. ABS are even more important for many emerging economies. The analysis of the Visegrád countries revealed that despite of just a few years of development of advanced services in Central and Eastern Europe, they already play an important role as ABS providers.

A bigger challenge is to analyse FDI in knowledge-intensive services. Aggregate statistics are not useful for long-term analysis or drawing international comparisons. Before stating any policy recommendations regarding the international role of ABS, much more effort has to be made by official statistics providers to ensure access to reliable data. This is a serious issue as most ABS and digital services are being exchanged between MNCs and constitute an important element of global value chains.

The main policy recommendation in order to increase the role of services is to continue efforts towards liberalization. In recent years, in spite of numerous declarations, progress in this matter has not been sufficient. Unfortunately, the current political and social atmosphere does not support this objective. Therefore, higher trade dynamics are expected in services not requiring physical presence in the country of provision, i.e., ABS, whose development is not directly influenced by policy changes, but rather strategies of MNCs pursuing an optimal international configuration of their operations.

\section{Acknowledgements, sources of financing}

Project financed by the Polish National Science Centre, decision no. DEC-2015/19/B/HS4/00356. 


\section{References}

Andersen B., Howells J., Hull R., Miles I., Roberts J., 2000, Knowledge and innovation in the new service economy, Cheltenham, Edward Elgar.

Bieron B., Ahmed U., 2016, The E15 initiative strengthening the global trade system (services, international rulemaking, and the digitization of global commerce), Journal of Commerce \& Management Thought, vol. 2.

Brandao Fischer B., 2015, On the contributions of knowledge-intensive business-services multinationals to Laggard innovation systems, Brazilian Administrative Review, vol. 12, no. 2.

Dettmer B., 2014, International service transactions: Is time a trade barrier in a connected world?, International Economic Journal, vol. 28, no. 2.

Engman M., 2007, Expanding international supply chains: The role of emerging economies in providing IT and business process services, OECD Trade Policy Working Paper no. 52.

Grossman G.M., Rossi-Hansberg E., 2008, Trading tasks: A simple theory of offshoring, American Economic Review, vol. 98, no. 5.

Jones R., Kierzkowski H., 2001, A framework for fragmentation, [in:] S. Arndt, H. Kierzkowski, Fragmentation: New Production Patterns in the World Economy, Oxford, Oxford University Press.

Low P., 2013, The role of service, [in:] D. Elms, P. Low, Global value chains in a changing world, Geneva, World Trade Organisation.

Markusen J. R., 1997, Trade versus investment liberalization, NBER Working Paper no. 6231.

Markusen J., Rutherford T., Tarr D., 2005, Trade and direct investment in producer services and the domestic market for expertise, The Canadian Journal of Economics. Revue canadienne d'Economique, vol. 38, no. 3.

Miles I., Kastrinos N., Flanagan K., Bilderbeek R., Hertog P., Huntink W., Bouman M., 1995, Knowledge-intensive business services: Users, carriers and sources of innovation, Luxemburg, EIMS Publication No. 15, Innovation Programme, Directorate General for Telecommunications, Information Market and Exploitation of Research, Commission of the European Communities.

Nath H., Liu L., 2017, Information and communications technology (ICT) and services trade, Information Economics and Policy, vol. 41.

Roberts J., 2003, Competitiveness in the business services sector: Implications for the competitivess of the European economy, Competition \& Change, vol. 7, no. 2-3.

Wirzt J., Tuzovic S., Ehret M., 2015, Global business services: Increasing specialization and integration of the world economy as drivers of economic growth, Journal of Service Management, vol. 26, issue 4.

WTO, 2015, Trade in services, https://www.wto.org/english/thewto_e/20y_e/services_brochure 2015_e.pdf [access: 03.02.2018].

A. Klimek (®) artur.klimek@ue.wroc.pl

Uniwersytet Ekonomiczny we Wrocławiu, ul. Komandorska 118/120, 53-345 Wrocław, Polska 